\title{
Implications of Non-Carbonate Dolomite Minerals in the Formation of Red Soils in a Paleokarstic Context in the Taoudeni Basin in Burkina Faso
}

\author{
Fidèle Kaboré1, Gounwendmanaghré Hubert Zongo² ${ }^{2}$, Bright Fafali Dogbey ${ }^{3}$, \\ Korodjouma Ouattara ${ }^{4}$, Younoussa Millogo ${ }^{5}$, Limata Kaboré6, Edmond Hien ${ }^{1,7}$, \\ Prosper N. Zombré1
}

\author{
${ }^{1}$ Laboratoire Sols, Matériaux et Environnement (LSME), Université Joseph KI-ZERBO, Ouagadougou, Burkina Faso \\ ${ }^{2}$ Laboratoire de Géosciences et Environnement Minier, Université de Fada, Ouagadougou, Burkina Faso \\ ${ }^{3}$ Department of Soil Resources Management, CSIR-College of Science and Technology, Accra, Ghana \\ ${ }^{4}$ Institut de l'Environnement et de Recherches Agricoles (INERA), Ouagadougou, Burkina Faso \\ ${ }^{5}$ Unité de Formation et de Recherche en Sciences et Techniques (UFR/ST), Université Nazi BONI, \\ Bobo-Dioulasso, Burkina Faso \\ ${ }^{6}$ Bureau des Mines et de la Géologie du Burkina Faso (BUMIGEB), Ouagadougou, Burkina Faso \\ ${ }^{7}$ Institut de Recherche pour le Développement (IRD), Montpellier, France \\ Email: fidele_kabore@hotmail.com
}

How to cite this paper: Kaboré, F., Zongo, G.H., Dogbey, B.F., Ouattara, K., Millogo, Y., Kaboré, L., Hien, E. and Zombré, P.N. (2021) Implications of Non-Carbonate Dolomite Minerals in the Formation of Red Soils in a Paleokarstic Context in the Taoudeni Basin in Burkina Faso. Open Journal of Soil Science, 11, 59-71.

https://doi.org/10.4236/ojss.2021.112004

Received: December 30, 2020

Accepted: February 16, 2021

Published: February 19, 2021

Copyright $\odot 2021$ by author(s) and Scientific Research Publishing Inc. This work is licensed under the Creative Commons Attribution International License (CC BY 4.0).

http://creativecommons.org/licenses/by/4.0/ (c) (i) Open Access

\begin{abstract}
Uncertainties remain as to the ability of certain carbonate rocks to form the red soils covering them. These doubts, which have been the subject of debate for several decades, become real when carbonate rocks are pure and low in insoluble residues. In the carbonate rocks of the Taoudeni basin in Burkina Faso, brown-red to red soils develop, at the top of hillsides and in karstic cavities. No study in the region has yet shown the existence in these carbonate rocks of sufficient insolubles to form soils after decalcification. The objective of this study was therefore to identify and quantify the minerals of carbonate rocks in order to identify the origin of red soils. Petrographic, chemical (XRF) and mineralogical (XRD) investigations on dominant carbonate rocks features in the study area show that the rocks studied are mainly magnesian dolomites (Dolomite $>50 \%$ of carbonate minerals and $\mathrm{Ca} / \mathrm{Mg}$ ratio $<1.5$ ). Non-carbonate residues from detrital and hydrothermal origin, negligible in certain pure dolomites $(<2 \%)$, are on the other hand significant $(>12 \%)$ in other dolomitic features. These insoluble silicates formed of quartz, potassium feldspar (orthoclase), clays (talc, phlogopite and kaolinite) and iron
\end{abstract}


oxides constitute the main original material of reddened soils in karstic cavities.

\section{Keywords}

Dolostone, Mineralogy, Parent Material, Alteration, Rubification

\section{Introduction}

Across the world, many studies have been carried out on the mechanism of formation of red soils on carbonate rocks. These studies are more widespread in the Mediterranean and temperate regions [1] [2]. In the tropics, studies of the formation of these soils are limited and recent [3] [4]. The debates on these soils focus on their mechanism of formation. Indeed, some authors doubt the ability of pure carbonate rocks to provide enough insoluble residues to develop soils [5]. Others, on the other hand, have found residues in certain carbonate rocks in sufficient quantity to form soils [6] [7]. On the carbonate rocks of Burkina Faso, in tropical regions, authors had already been mentioned the presence of rubified soils [8] [9], without specifying the mechanism of their establishment. In addition, no study in these carbonate rocks has yet proven the existence of insolubles in sufficient quantity to form soils after the carbonates have dissolved. The various analyses carried out on these carbonates are essentially chemical analysis to determine the potential of the rock in the cement industry and in the amendment of acidic soils [10]. However, this chemical analysis remains limited in the identification of the minerals facies that make up carbonate rocks due to the mixture of sediments [11]. A mineralogical study of carbonate rocks is therefore necessary to identify and quantify the insoluble phases contained in these carbonates. The mineralogical studies already carried out on these rocks relate mainly to the description under an optical microscope [9]. Even though this technique is effective, it is difficult to accurately detect certain residues (clays), very small sizes of the micron order, trapped in carbonate rock [11]. The present study, which uses modern methods of chemical composition (XRF) and mineralogical (DRX), aims to determine and quantify the minerals of these carbonate rocks in order to understand the mechanism of formation of red soils after decalcification.

\section{General Framework of the Study Area}

The study was carried out in the Western Region of Burkina Faso (Figure 1). The existence of carbonate rocks in this South-Eastern edge of the Taoudeni basin had already been reported by [8] [12]. The climate encountered is Sudanese, characterized by a long dry season and a short rainy season. The average annual rainfall is over $900 \mathrm{~mm}$. The average temperature is $19^{\circ} \mathrm{C}$ for the minimum and $35^{\circ} \mathrm{C}$ for the maximum. The vegetation found on the hills of carbonate rock is mainly formed by relics of clear forests consisting of Terminalia macroptera 


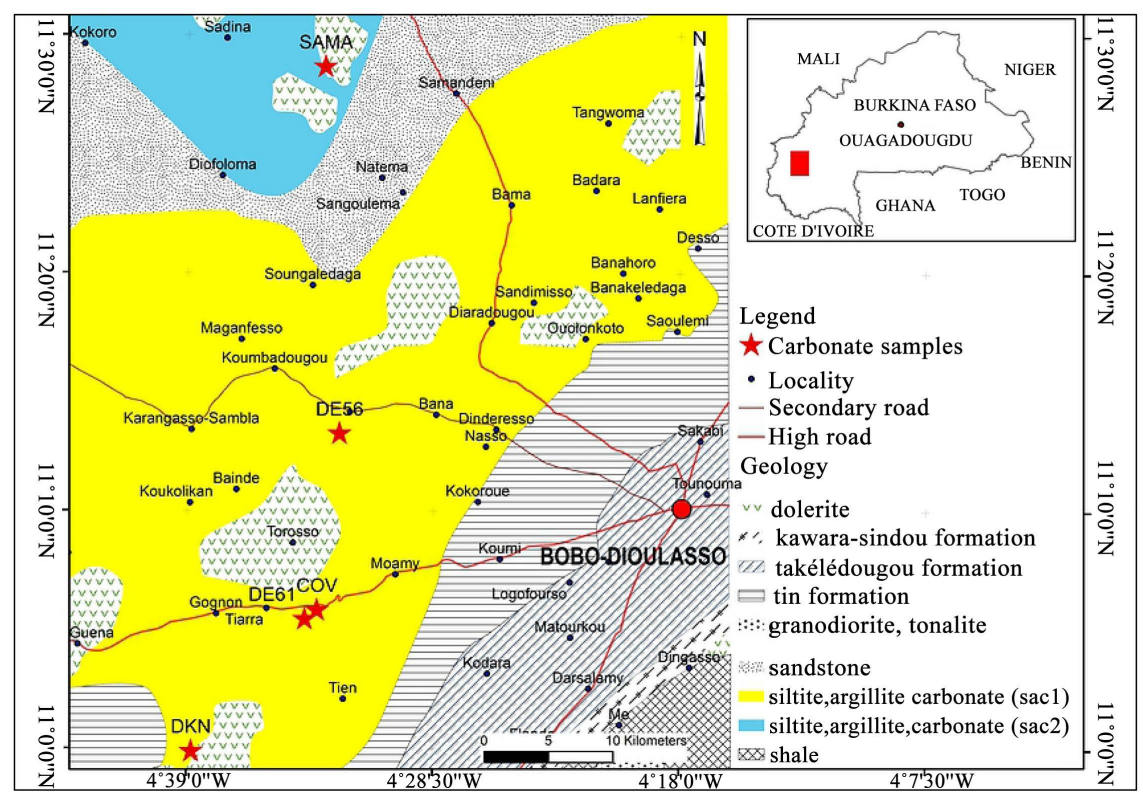

Figure 1. Geographic location, geology and sampling points of carbonate rocks.

Guill. and Perr., Mitragyna inermis (Willd.) Kuntze, Berlinia grandiflora (Vahl) Hutch. and Dalziel, Parkia biglobosa (Jacq.) R.Br. ex G.Don, Guiera senegalensis J. F. Gmel., Lannea microcarpa (Engl. and K. Krause) etc. Surrounding carbonate hills, two main soil classes (Leptosols and Lixisols) were identified [13]. The geomorphology of this region is formed by lateritic plateau, broad valleys (plains and peripheral depressions) and a few mounds and hills. The hydrographic network is formed by the country's largest river (Mouhoun) and its tributaries.

The geology of the study area is made up of sedimentary rocks marked by intrusions of plutons. The two stratigraphic formations containing carbonate rocks are Guéna-Souroukoudinga (SAC1) and Samendéni-Kiéba (SAC2) (Figure 1). These two formations do not show significant differences, but rather constitute a vast series separated by an episode of temporarily coarser sandstone sedimentation [14].

The most widespread carbonate rock features are of two large groups: very dominant stromatolite carbonate rocks and granular, oolitic to pisolithic carbonate rocks [8] [9]. Alongside these two main features, bedded carbonate rocks, silicified carbonate rocks and very few marls are identified. This study aims on the one hand to determine and quantify the different carbonate and non-carbonate minerals of dominant carbonate rock features in the region. On the other hand, it seeks to show the role of insoluble residues resulting from the dissolution of hard and compact carbonates in the formation of red soils trapped in karst cavities. For this purpose, only the hard and compact carbonate formations composed of the two dominant features (stromatolites carbonate rocks and granular carbonate rocks) were collected. Indeed, the few thin and soft layers of marl observed could not control the pedogenesis on these large layers of hard and compact carbonate rocks. Thus, the marls which are very much in the minority 
compared to the two carbonate rock features mentioned above were not sampled [12].

\section{Methodology}

\subsection{Sampling of Carbonate Rocks}

For microscopic, chemical and mineralogical analysis, five samples of the most widespread carbonate rocks were obtained. These are three samples of stromatolite carbonate rocks, one sample of granular carbonate rock (oolitic) and one sample of finely bedded carbonate rock that is relatively poorly represented. Samples were taken from hills of carbonate rocks (Figure 1).

\subsection{Sampling of Soils from Carbonate Rocks Weathering}

Two types of soils of different colors were sampled in a cavity adjacent to the place where the SAMA sample was taken (Figure 1). This cavity was recently laid bare in Samendéni's new carbonate quarry. In this dissolution structure, the soil is red above and brown to yellowish below (Munsell Soil color charts). Hydrochloric acid ( $\mathrm{HCl} 10 \%)$ was used to test the presence of active calcareous in both soils.

\subsection{Laboratory Analysis}

The collected rock samples were subjected to a macroscopic description in thin sections using a polarizing microscope. A slice of each sample was then ground into fine particles of 75 microns for chemical fluorescence-ray (XRF) and mineralogical X-ray diffraction (XRD) analysis. Mass composition of carbonate rocks minerals was determined by calculation method using data from mineralogical (XRD) and chemical (XRF) analysis [15].

The two soil samples taken were dried and separated into three fractions (250 microns, 500 microns and $2 \mathrm{~mm}$ ). The 250 micron fraction was used for total geochemistry using the XRF device [16] [17]. The 500 micron fraction was used for the determination of cation exchange capacity (CEC) after extraction using a solution of $0.01 \mathrm{M}$ silver thiourea. Finally, the $2 \mathrm{~mm}$ batch was used for particle size analysis by the hydrometer method and for the determination of the organic matter (OM) by the Walkley and Black method [18].

\subsection{Creation of Maps, Figures and Tables}

The maps were produced using ArcGIS 10.2 software. ArcGis is a software package for operating a Geographic Information System (GIS). This software allows the acquisition, storage, updating, manipulation, and processing of geographic data. In addition, it intervenes in the cartography and the spatial analysis in a precise way according to the desired scale. Tables and figures were generated using Microsoft Excel 2010 spreadsheet. The images were edited using CorelDRAWX5 software. CorelDRAW X5 is a very useful graphics editor for designing illustrations. 


\section{Presentation of the Results}

\subsection{Petrographic Study of Carbonate Rocks}

Sample (COV): hard, compact and white-pinkish carbonate rock. In contact with dilute acid, this rock shows a weak effervescent. This dolostone consists of fine stromatolitic laminations with a wavy appearance. Under the polarizing microscope (A1 and A2) in Figure 2, the rock is formed of fine grains (dolomicrite). This Dolomicrite rock is weakly affected by hydrothermal alteration. The dolostone is affected by two phases of brittle deformation highlighted by a cut infra-millimeter joints which are occupied by phenocrystals of recrystallized carbonates. Certain joints are to run parallel with bedding and the others are run perpendicular Cv1 and Cv2. Small opaque's minerals are in relation with calcite

Sample DE56: Rock is gray, hard, and compact with fine corrugated stromatolite laminations identical to rock (COV). This carbonate rock shows very slight effervescence on contact with dilute acid. Microscopic study of the sample reveals a fine-grained dolomite (dolomicrite). Hydrothermal alteration induces the recrystallization of most coarse grains of calcite to subgrains. It is locally accompanied by magnetite crystallization.

Sample (DE61): compact, hard, and, gray carbonate rock with stromatolite laminations in the shape of a saucer stack. It shows a strong localized effervescence on contact with diluted $\mathrm{HCl}$. Under the microscope (D1 and D2) in Figure 2, the rock consists of fine to medium (subhedral) dolomitic grains partially recrystallized. The rock is affected by ductile to brittle deformations. The ductile deformation zones are partially silicified and marked by the crystallization of the albite. It locally contains numerous recrystallized coarse grains of calcite and the hydrothermal fluids are accompanied by crystallization of magnetite.
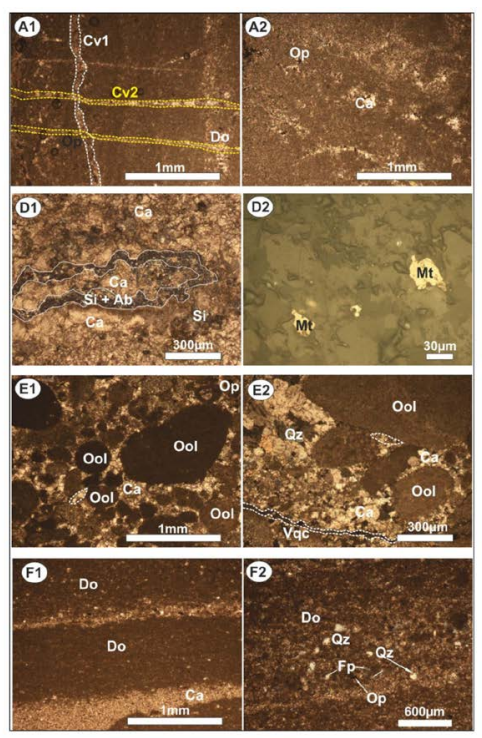

Do: dolomite; Ca: calcite; Qz: quartz; Op: opaque; Fp: feldspar;

Si: silica; Ab: albite; Mt: Magnetite; Cv1: carbonate vein 1; $\mathrm{Cv}$ 2: carbonate vein; Vqc: quartz and carbonate vein

Figure 2. Microscopic description of carbonate rocks. 
Sample DKN: Rock is whitish, hard and formed of oolites. The diluted $\mathrm{HCl}$ test shows a strong generalized effervescence. A thin whitish layer of weathering lines the surface of the sample. Under the microscope (E1 and E2) in Figure 2, the oolites united locally by calcite sparite cement are completely dolomitized and represent the primary dolomite. Secondary dolomite corresponds to authigenic dolomite. These dolomitic grains have a wide range of characteristics including variations in grain-size. Their grain shapes are planar (eudhral) to irregular edges and having crystallized within the detrital matter. Detrital quartz arenite and recrystallized carbonate formed the matrix of the rock. Late carbonate and quartz filling joints owing to brittle deformation affect the rock locally.

SAMA sample: Grayish carbonate rock, hard and bedded. It deteriorates in the form of a thin whitish to yellowish layer. On contact with diluted $\mathrm{HCl}$, a strong effervescence occurs locally. The microscope study (F1 and F2) in Figure 2 shows this dolomicrite is composed of an alternation of dark beds of dolomite and clear beds of calcite. Grains of quartz and potassium feldspar are scattered throughout the dolomicrite.

\subsubsection{Geochemical Composition (XRF)}

The levels of $\mathrm{CaO}$ and $\mathrm{MgO}$ are respectively between (25.87 to $31.00 \%$ ) and (13.80 to $20.90 \%)$ indicate that they are dolomites. The silica $\left(\mathrm{SiO}_{2}\right)$ content which varies from 1.32 to 8.91 reveals the presence of silicate minerals of variable content (Table 1).

Manganese $\left(\mathrm{MnO}_{2}\right)$ and iron $\left(\mathrm{Fe}_{2} \mathrm{O}_{3}\right)$ are ubiquitous in these dolomites. The levels of $\left(\mathrm{Fe}_{2} \mathrm{O}_{3}\right)$ are between $0.75 \%$ and $2.57 \%$ and those of $\mathrm{MnO}_{2}$ are between $0.02 \%$ and $0.06 \%$. Aluminium $\left(\mathrm{Al}_{2} \mathrm{O}_{3}\right)$ and potassium $\left(\mathrm{K}_{2} \mathrm{O}\right)$ which enters the network of certain silicate minerals are sometimes below the detection limit. The $\mathrm{Ca} / \mathrm{Mg}$ ratio of carbonates is between 1 and 1.5. Strontium ( $\mathrm{Sr}$ ) remains the predominant trace element in these carbonates, but its content is $<500 \mathrm{ppm}$. Losses on ignition generally $>40 \%$ correspond to $\mathrm{CO}_{2}$ losses from dolomites.

\subsubsection{Mineralogical Characterization (XRD) of Rock Samples}

Carbonate minerals are the main constituents of rocks. Dolomite is the most common mineral in these carbonates; its main peak appears at $2.89 \AA$ (Figure 3).

Table 1. Geochemistry of carbonate rocks.

\begin{tabular}{cccccccccccccc}
\hline Samples & $\mathrm{CaO}(\%)$ & $\mathrm{MgO}(\%)$ & $\mathrm{SiO}_{2}(\%)$ & $\mathrm{TiO}_{2}(\%)$ & $\mathrm{Fe}_{2} \mathrm{O}_{3}(\%)$ & $\mathrm{Al}_{2} \mathrm{O}_{3}(\%)$ & $\mathrm{SO}_{2}(\%)$ & $\mathrm{MnO}_{2}(\%)$ & $\mathrm{P}_{2} \mathrm{O}_{5}(\%)$ & $\mathrm{K}_{2} \mathrm{O}(\%)$ & $\mathrm{Sr}(\mathrm{ppm})$ & $\mathrm{LOI}(\%)$ & $\mathrm{Ca} / \mathrm{Mg}$ \\
\hline $\mathrm{DE} 61$ & 29.50 & 14.48 & 3.56 & 0.05 & 0.91 & $<\mathrm{DL}$ & $<\mathrm{DL}$ & 0.03 & 0.80 & 0.34 & 283.99 & 49.33 & 1.5 \\
$\mathrm{COV}$ & 28.67 & 19.09 & 3.99 & 0.08 & 1.31 & 0.99 & 0.02 & 0.02 & 0.80 & 1.15 & 241.85 & 42.43 & 1.1 \\
$\mathrm{DE} 56$ & 30.62 & 20.90 & 1.32 & 0.03 & 0.75 & $<\mathrm{DL}$ & 0.03 & 0.02 & 0.76 & 0.19 & 327.73 & 44.38 & 1.1 \\
$\mathrm{SAM}$ & 25.87 & 13.80 & 8.91 & 0.14 & 2.57 & 1.88 & 0.04 & 0.05 & 0.95 & 1.70 & 84.65 & 42.63 & 1.4 \\
DKN & 31.00 & 15.76 & 3.75 & $<\mathrm{DL}$ & 2.50 & $<\mathrm{DL}$ & 0.03 & 0.06 & 0.77 & $<\mathrm{DL}$ & 203.95 & 45.14 & 1.3 \\
\hline
\end{tabular}

LOI: Losses on ignition; $<$ DL: Less than detection limit. 

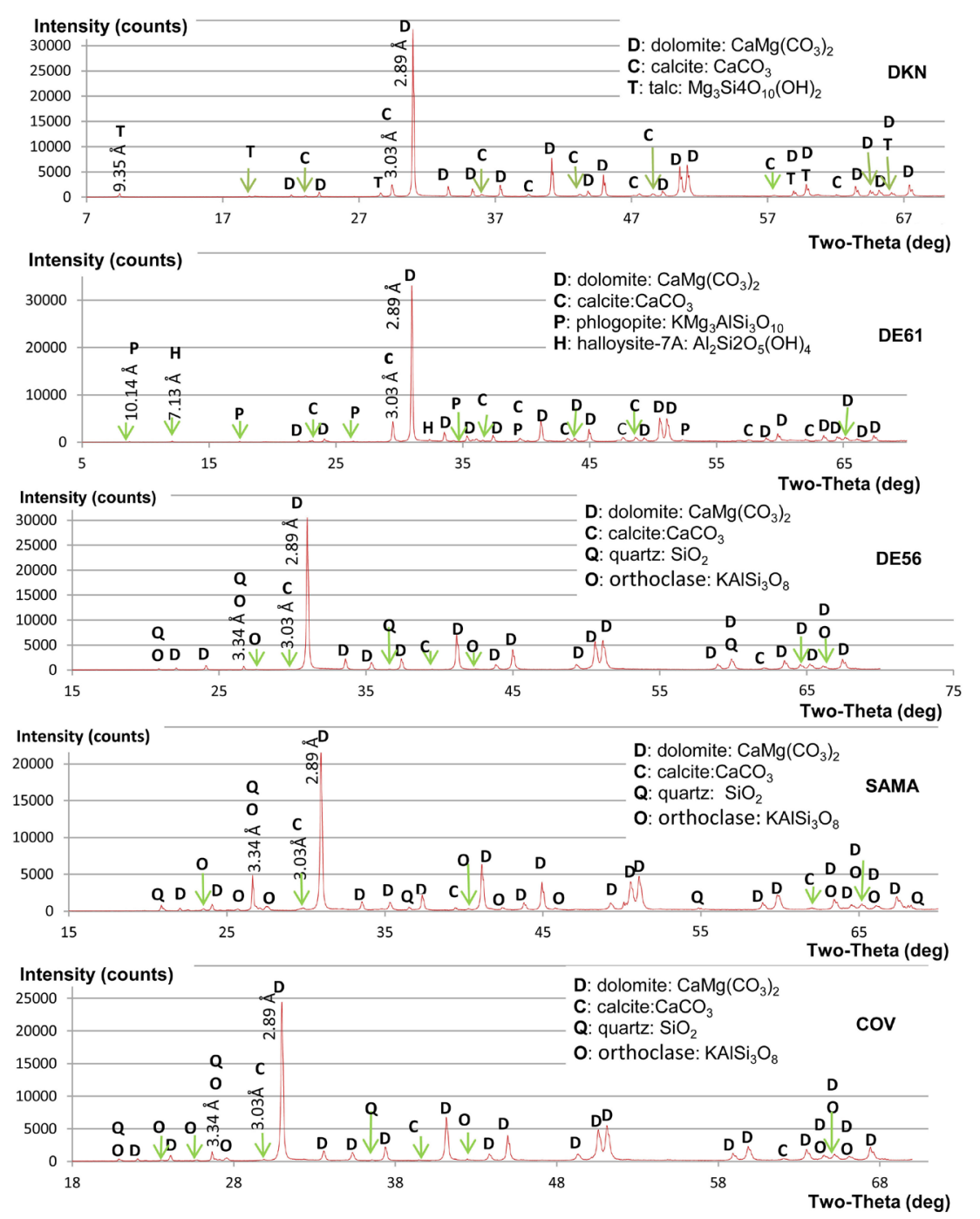

Figure 3. XRD of carbonate rocks.

Calcite is weakly represented in these carbonate rocks. The samples (DNK and DE61) in which the calcite content is significant, the main peak of the mineral clearly appears at $3.03 \AA$ (Figure 3). Quartz and orthoclase (potassium feldspar) are silicate minerals, prevalent in these rocks. Quartz's main peak appears at 3.34 $\AA$. The main peak of orthoclase in these carbonates remains confused with that of quartz at $3.34 \AA$. The silicate clay minerals identified are: Phlogopite whose main peak occurs at $10.14 \AA$, halloysite-7 $\AA$ or hydrokaolinite whose main peak appears at $7.13 \AA$ and talc whose main peaks at $9.35 \AA$.

The contents of carbonate minerals (dolomite and calcite) in the rocks range from $60 \%$ to $75 \%$. Dolomite still constitutes more than $60 \%$ of the carbonates in the rock. Calcite does not make more than $30 \%$ of carbonates (Table 2).

As for non-carbonate minerals, their contents vary from $1 \%$ in pure features (low in residue) to around $12 \%$ in features rich in insoluble. These insoluble residues are released more or less quickly depending on the dominant mode of alteration which is dependent on the hardness of the dolomitic rock. 
Table 2. Mass composition of carbonate rocks minerals from calculation method.

\begin{tabular}{|c|c|c|c|c|c|c|c|c|c|}
\hline \multirow{3}{*}{ Samples } & \multicolumn{3}{|c|}{ Carbonate minerals } & \multicolumn{6}{|c|}{ Non-carbonate minerals } \\
\hline & \multirow{2}{*}{$\mathrm{Ca}$} & \multirow{2}{*}{ Do } & \multirow{2}{*}{$\begin{array}{l}\text { Total } \\
(\%)\end{array}$} & \multirow{2}{*}{ Qz } & \multirow{2}{*}{$\begin{array}{c}\text { Feldspar } \\
\text { Orth }\end{array}$} & \multicolumn{3}{|c|}{ Clay } & \multirow{2}{*}{$\begin{array}{c}\text { Total } \\
(\%)\end{array}$} \\
\hline & & & & & & Tal & $\mathrm{Phl}$ & $\mathrm{Hal}$ & \\
\hline DE56 & 3.25 & 72.06 & 75.31 & 0.60 & 1.11 & - & - & - & 1.71 \\
\hline DE61 & 19.23 & 46.83 & 66.06 & - & - & - & 3.1 & 4.70 & 7.8 \\
\hline $\mathrm{COV}$ & 4.76 & 65.82 & 70.58 & 1.01 & 5.40 & - & - & - & 6.41 \\
\hline DKN & 21.21 & 47.80 & 69.01 & - & - & 5.95 & - & - & 5.95 \\
\hline SAMA & 12.62 & 47.58 & 60.00 & 2.41 & 10.26 & - & - & - & 12.67 \\
\hline
\end{tabular}

Ca: Calcite (\%); Do: Dolomite (\%); Qz: Quartz (\%); Tal: Talc (\%); Phl: Phlogopite (\%); Hal: Halloysite (\%); Orth: orthoclase (\%).

\subsubsection{Pellicular Alteration of Dolostones and Soils Rubification in Cavity} The process of red soils formation from these dolomites can be split into two stages: dolomitic rock to yellowish brown soil and yellowish-brown soil to red soil above (Figure 4).

The weathering of dolostone into yellowish brown soil is accompanied by a significant loss of carbonates $(\mathrm{MgO}$ and $\mathrm{CaO})$ against a concentration of $\mathrm{SiO}_{2}$, $\mathrm{Fe}_{2} \mathrm{O}_{3}, \mathrm{Al}_{2} \mathrm{O}_{3}, \mathrm{~K}_{2} \mathrm{O}$ (Table 1 and Figure 5). Changing from yellowish brown soil to red soil is followed by the losses of $\mathrm{MgO}, \mathrm{SiO}_{2}, \mathrm{Fe}_{2} \mathrm{O}_{3}$ and $\mathrm{K}_{2} \mathrm{O}$. In the mean-time $\mathrm{Al}_{2} \mathrm{O}_{3}$ content increases (Figure 5).

Some of the clay is still found as silty pseudo-particles in yellowish brown soil. The sand content remains invariable and the organic matter content is low $(<1 \%)$ in to the two soil types (Table 3 ).

The chemical analysis indicates the silica/alumina $\left(\mathrm{SiO}_{2} / \mathrm{Al}_{2} \mathrm{O}_{3}\right)$ ratio is close to 2 for the red soil and greater than 2 for the yellowish-brown soil. In these soils come from dolostone weathering, iron is the most important element after silica.

\section{Discussion}

Petrographic, chemical and mineralogical analysis of the rocks shows that they are all dolomites. The $\mathrm{Ca} / \mathrm{Mg}$ ratio of these dolomites is between 1 and 1.5 , they are magnesian dolomites [19]. The levels of iron and manganese are relatively high in these carbonate rocks. This supposes that their formation took place in a reducing environment, particularly, in the Precambrian [20]. Indeed, marine waters at that time were rich in $\mathrm{Fe}$ and $\mathrm{Mn}$ due to the oxygen poverty, responsible for reducing conditions [21] [22]. The numerous stromatolithic laminations and oolitic features encountered suggest a warm, shallow sea, agitated at times, in which the algae Cyanophyceae (stromatolites) proliferated. The presence of bedded features indicates rhythmic deposits linked to variations in the chemical composition of the water and to significant terrigenous inputs [23]. The level of $\mathrm{Sr}$ is lower than those obtained in the carbonates formed in hypersaline environment [21]. That supposes sea water salinity was variable [9]. The lower value of $\mathrm{Sr}$ observed in the SAMA sample would mean a relatively important 


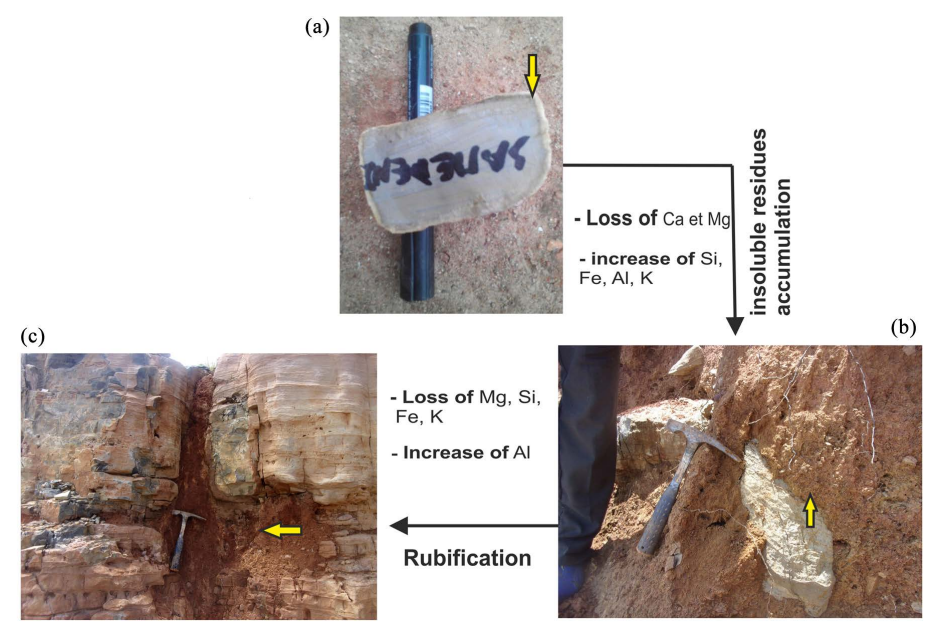

Figure 4. Stages of red soil formation in a karstic cavity. (a): Dolomitic pellicular alteration; (b): Yellowish brown soil; (c): Red soil.

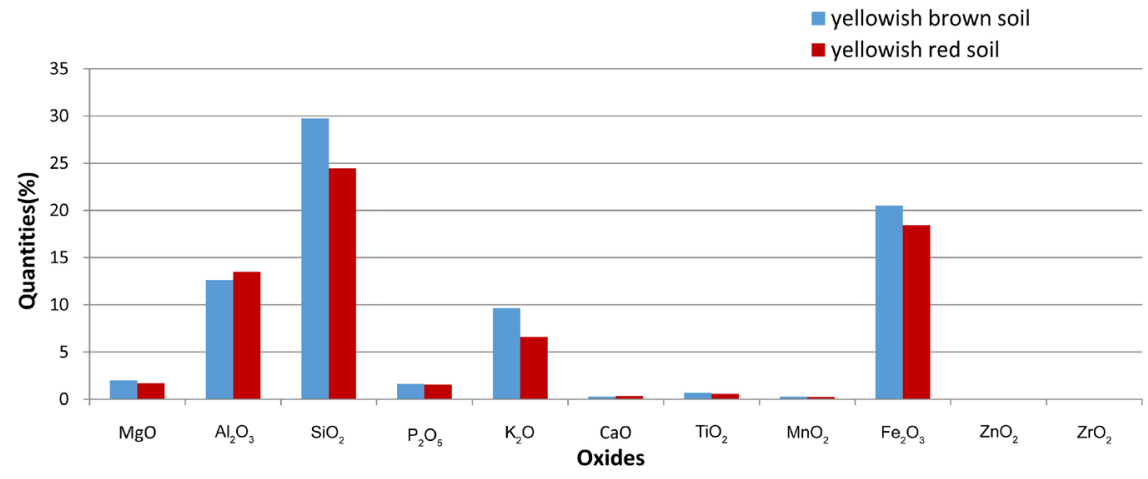

Figure 5. Oxide contents in the two types of decalcification soils.

Table 3. Comparison of some morphological, physical and chemical characteristics of the two soils.

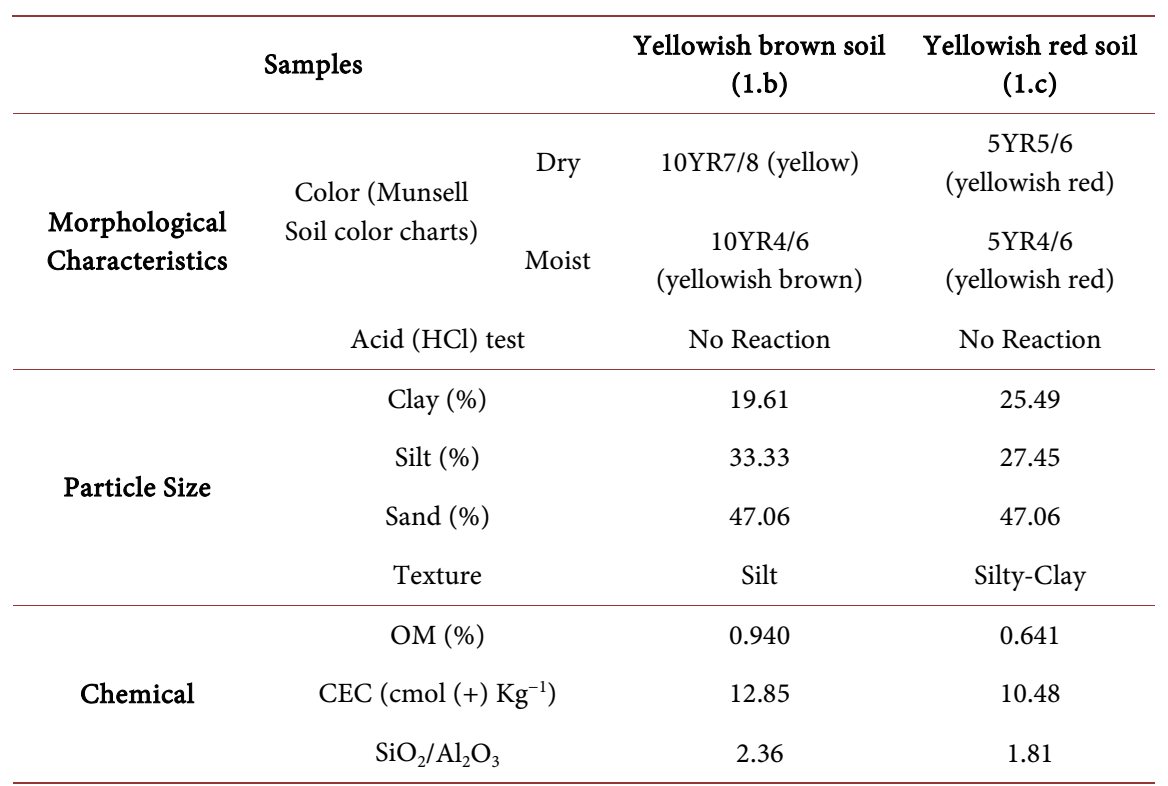

CEC: Cation Exchange Capacity; OM: Organic Matter. 
alteration in this rock. In principle, old carbonates such as those studied are formed mainly of calcites, dolomites and few terrigenous elements [21]. However, the tectonic phenomena linked to the intrusion of dolerites in the form of veins, dykes and lacoliths caused a significant circulation of hydrothermal fluids in the dolomite. These fluids enriched in silica would have favored the crystallization of new silicate minerals (quartz, feldspars, talc, phlogopite, hydrated kaolinite) and iron oxides etc. [20] [21] [24]. In the veins, quartz crystals are associated with recrystallized calcite phenocrystals. In pure dolomitic features, the residue content (silicate minerals) remains negligible. However, the level of insoluble residues can be higher in other dolomites rich in impurities. The accumulation of these non-carbonate residues is sufficient to form soils and provide them with almost all of the chemical elements they contain [7]. The release of residues trapped in these carbonates takes place during dolomite rocks weathering.

In these predominantly hard carbonate rocks, pellicular alteration predominates. This type of alteration is favorable to the development of karstic relief [1] [25]. In the wet season, rainwater loaded with $\mathrm{CO}_{2}$ dissolves carbonates. It then forms thin alteration layer corresponding to the thin whitish to yellowish layer on the surface of the carbonates (Figure 4). The scarcity of major karst networks such as identified in other regions, responsible for residue losses by deep entrainment [1] [25], the residues from these dolostones gradually accumulate in minor forms of dissolution (cavities). These insoluble residues first form a loose, silty, yellowish-brown soil. The negative test for diluted hydrochloric acid $(\mathrm{HCl})$ in this soil indicates the evacuation of active calcareous and almost all decalcification [1]. The soil gradually loses silica and alkaline earths from top to bottom by leaching. The elimination of these cations in the upper level of the soil would promote the crystallization of hematite, iron oxide responsible for the red tint [5] [26]. In the lower part of the cavity, on the other hand, the soil is poorly drained, thus creating a temporary hydromorphy favorable to the dissolution of a large quantity of carbonates and to the appearance of the brown tint with a yellowish background of goethite, hydroxide of iron [26]. Soil rubefaction would result in an alteration of goethite into hematite when it is well drained [2]. Iron, the second most important element in these soils, plays a major role in the development of the red tint [5]. Red soil is therefore an evolved form of yellowish-brown soil. This is confirmed by the invariable sand content, attesting to the same origin of these two soils. The pedogenetic phenomenon that allows the formation of red soils in these dolostone is rubification [2] [4]. Certain clays, still in the form of silty pseudo-particles in the yellowish-brown soil are gradually released into the red soil, causing an increase in the clay content in the latter. The $\mathrm{SiO}_{2} / \mathrm{Al}_{2} \mathrm{O}_{3}$ ratio and the average CEC despite the low organic matter content suggest the coexistence of type 2/1 clays alongside non-swelling type 1/1 clays in soils. However, the losses of silica and alkaline earth, while the alumina level increases could explain the drop in the $\mathrm{SiO}_{2} / \mathrm{Al}_{2} \mathrm{O}_{3}$ ratio from yellowish-brown soil to red soil. Lowering the $\mathrm{SiO}_{2} / \mathrm{Al}_{2} \mathrm{O}_{3}$ ratio and the $\mathrm{CEC}$ assumes 
a gradual transformation of type $2 / 1$ clays into $1 / 1$ type clay such as kaolinite [7] [27]. The evolution of soils resulting from the alteration of these dolostones is comparable to that of tropical red soils of the fersialitic soils subclass, in which type $2 / 1$ clays gradually degrade into type $1 / 1$ kaolinite [1].

\section{Conclusion}

The carbonate rocks of Western Burkina Faso are mainly magnesian dolomites. The non-carbonate minerals identified in these dolomitic rocks are mainly quartz, feldspars and clays. These silicate residues are of both hydrothermal and detrital origin. The circulation of hydrothermal fluids due to the intrusion of dolerites in the Quaternary would be at the origin of the many silicifications in these rocks. The residue content, negligible in pure dolomitic features, is however high in dolomite and rich in impurities. These insoluble matters form most of the original material of the red soils identified at the top of the slope and in the karstic cavities of the dolomitic hills. The formation of red soils favored by heavy rainfall and good drainage occurs gradually. Pedogenesis in these dolostones is characterized by high losses of calcium and magnesium from the first moments of weathering. The rubification of soils is also accompanied by a loss of silica against an increase in alumina. The high $\mathrm{CEC}, \mathrm{K}_{2} \mathrm{O}$ and $\mathrm{SiO}_{2} / \mathrm{Al}_{2} \mathrm{O}_{3}$ ratio in yellowish-brown soil decreases as reddening continues in red soil, thus recalling a gradual transformation of type $2 / 1$ clays into type clay $1 / 1$. The evolution of these studied soils is similar to that of tropical red soils resulting from fersialitic pedogenesis.

\section{Acknowledgements}

We thank managers and staff of the Laboratory of Mines and Geology Office of Burkina Faso (BUMIGEB) for making their XRF device available to us. We thank Professor Philippe Blanchart of Laboratory of Ceramic Research Institute/IRCER/Limoges, France for having accepted to help us in the XRD mineralogical analysis.

\section{Conflicts of Interest}

The authors declare no conflicts of interest regarding the publication of this paper.

\section{References}

[1] Durn, G. (2003) Terra Rossa in the Mediterranean Region: Parent Materials, Composition and Origin. Geologia Croatica, 56, 83-100.

[2] Fedoroff, N. and Courty, M.A. (2013) Revisiting the Genesis of Red Mediterranean Soils. Turkish Journal of Earth Sciences, 22, 359-375.

[3] Febles González, J.M., Febles Díaz, J.M., Sobrinho, N.M.B.A., Tolón-Becerra, A., Lastra-Bravo, X. and Botta, G.F. (2019) Resilience of Red Ferralitic Soils in the Karst Regions of Mayabeque Province, Cuba. Land Degradation \& Development, 30, 109-116. https://doi.org/10.1002/ldr.3192 
[4] Hajna, N.Z., Otoničar, B., Pruner, P., Culiberg, M., Hlaváč, J., Mandić, O. and Bosák, P. (2019) Late Pleistocene Lacustrine Sediments and Their Relation to Red Soils in the Northeastern Margin of the Dinaric Karst. Acta Carsologica, 48, 153-171. https://doi.org/10.3986/ac.v48i2.7080

[5] Muhs, D.R. and Budahn, J.R. (2009) Geochemical Evidence for African Dust and Volcanic Ash Inputs to Terra Rossa Soils on Carbonate Reef Terraces, Northern Jamaica, West Indies. Quaternary International, 196, 13-35.

https://doi.org/10.1016/j.quaint.2007.10.026

[6] Bronger, A. and Sedov, S.N. (2003) Vetusols and Paleosols: Natural versus Man-Induced Environmental Change in the Atlantic Coastal Region of Morocco. Quaternary International, 106, 33-60. https://doi.org/10.1016/S1040-6182(02)00160-X

[7] Baize, D., Van Oort, F. and Nédélec, H. (2016) Un facteur majeur de la pédogenèse après décarbonatation dans le cas des formations superficielles calcaires redistribuées au quaternaire: La nature des résidus non carbonatés. Etude et Gestion des Sols, 23, 173-192.

[8] Hugot, G. and Carbonnel, J.P. (1986) Le lapiaz de Souroukoudinga (Burkina Faso), un karst à micro-tourelles d'âge supposé quaternaire. Karstologia, 8, 31-38. https://doi.org/10.3406/karst.1986.2138

[9] Koussoube, Y. (2010) Hydrogéologie des séries sédimentaires de la dépression piézométrique du Gondo (bassin du Sourou): Burkina Faso/Mali (Doctoral Dissertation).

[10] Koulibaly, B., Dakuo, D., Traore, M., Traore, O., Nacro, H.B., Lompo, F. and Sedogo, M.P. (2016) Effets de la fertilisation potassique des sols ferrugineux tropicaux sur la nutrition minérale et la productivité du cotonnier (Gossypium hirsutum L.) au Burkina Faso. International Journal of Biological and Chemical Sciences, 10, 722-736. https://doi.org/10.4314/ijbcs.v10i2.22

[11] Hubert, F. (2008) Modélisation des diffractogrammes de minéraux argileux en assemblages complexes dans deux sols de climat tempéré: Implications minéralogique et pédologique (Doctoral Dissertation, Poitiers).

[12] Jonquet P. (1963) Prospection des dolomies dans le sédimentaire ouest-voltaïque. BRGM, secteur Haute-Volta, 55 p.

[13] Bunasols (2002) Etude morphopédologique de la province du Houet. Echelle 1:100000, p. 53. et annexes.

[14] Dakouré, D. (2003) Etude hydrogéologique et géochimique de la bordure sud-est du bassin sédimentaire de Taoudéni (Burkina Faso Mali). Essai de modélisation. Thèse doctorat, UPMC, $222 \mathrm{p}$.

[15] Miche, H., Simler, R., Affaton, P., Mickala, O., Boudzoumou, F. and Mbina, M. (2013) New Computerized Method for the Geochemical Classification of Precambrian Carbonate Rocks: Case of a Set of African Cap Carbonates. International Journal of Geosciences, 4, 37-49. https://doi.org/10.4236/ijg.2013.410A005

[16] Saat, A., Hamzah, Z. and Bakar, Z.A. (2008) XRF Determination of Major Elemental Contents of Clay Samples from North-West Peninsular Malaysia.

[17] Tomori, W.B., Yanful, E.K., Flemming, R.L., Amoo, I.A., Aiyesanmi, A.F. and Adekoya, J.A. (2016) Mineralogy and Geochemestry of Soil in Ondo Stat Bitum Environment, Nigeria.

[18] Walkley, A. and Black, I.A. (1934) An Examination of the Degtjareff Method for Determining Soil Organic Matter, and a Proposed Modification of the Chromic Acid Titration Method. Soil Science, 37, 29-38.

https://doi.org/10.1097/00010694-193401000-00003 
[19] Shchekina, T.I., Gramenitskii, E.N., Batanova, A.M., Kurbyko, T.A., Likhodievskii, A.V., Grigor'ev, B.N. and Pyrikov, A.N. (2006) Use of Magnesian-Dolomite Mixtures in Steel-Melting Furnace Hearths and the Mechanism of Their Wear in Service. 1. Study of Anker-harth Refractories. Refractories and Industrial Ceramics, 47, 317-325. https://doi.org/10.1007/s11148-006-0117-7

[20] Franchi, F. (2018) Petrographic and Geochemical Characterization of the Lower Transvaal Supergroup Stromatolitic Dolostones (Kanye Basin, Botswana). Precambrian Research, 310, 93-113. https://doi.org/10.1016/j.precamres.2018.02.018

[21] Warren, J. (2000) Dolomite: Occurrence, Evolution and Economically Important Associations. Earth-Science Reviews, 52, 1-81. https://doi.org/10.1016/S0012-8252(00)00022-2

[22] El Haddi, H. (2014) Les silicifications de la série phosphatée des Ouled Abdoun (Maastrichtien-Lutétien Maroc): Sédimentologie, Minéralogie, Géochimie et Contexte Génétique (Doctoral Dissertation).

[23] Miningou, M. (2006) Genèse des indices polymétallifères des formations néoprotérozoïques (1000-544 Ma) dans la région du Béli (Burkina Faso): Contrôle structural, nature des fluides, rôle de la silice (Doctoral Dissertation, Thèse Univ. Paul Cezanne Aix Marseille III).

[24] Seliem, M.K., Komarneni, S., Park, M., Katsuki, H., Shahien, M.G., Khalil, A.A. and Abd El-Gaid, I.M. (2010) Hydrothermal Synthesis of Mn-Kaolinite Using $\mathrm{NaOH}$ or $\mathrm{KOH}$ and Characterization. Applied Clay Science, 49, 74-79. https://doi.org/10.1016/j.clay.2010.04.006

[25] Baize, D. (2012) Les terres d'Aubues de Basse Bourgogne. Étude et Gestion des Sols, 19, 139-161.

[26] Pons, T. (2015) Caractérisation des oxy-hydroxydes de fer et des éléments associés (S, Se, As, Mo, V, Zr) dans les environnements redox favorables aux gisements d'uranium (Doctoral Dissertation).

[27] Zaki, O., Abdoulaye, A., Nomao, D.L., Rumori, P., Palomino, G.T. and Amadou, I. (2008) Caractérisation des Sols de Périmètres Irrigués de l'Ouest du Niger par Diffraction de Rayons X. Société Ouest Africaine de Chimie (SOACHIM), 26, 89-97. 